\title{
Semantics of IT Professionals Training
}

\author{
${ }^{1}$ Alfiya R. Baranova, ${ }^{2}$ Natalya A. Sigacheva \\ ${ }^{1,2}$ Kazan Federal University, Institute of International Relations \\ Email: baranova.alfiyarafailovna@mail.ru
}

Received: 20 ${ }^{\text {th }}$ August 2019, Accepted: $30^{\text {th }}$ September 2019, Published: $31^{\text {st }}$ October 2019

\begin{abstract}
Relevance of the issue under study is due to the fact that students and IT specialists often face the difficulties in use of terms, and consequently insufficient knowledge of English computer terminology affects the efficiency of their work. The purpose of the article is to analyze the impact of computer terminology awareness on professional skills and qualification of IT specialists. The leading approaches to the study are empirical, experimental (conducting a survey, a questionnaire). The results showed efficiency of using English computer terminology to increase professional skills of IT specialists. The research highlights that knowledge of English computer terminology is one of the important professional skills of IT specialists. The article may be useful for students, teachers, and specialists in the branch of IT and for all computer users.
\end{abstract}

\section{Keywords}

Language, Speech, Translation, Semantics, Linguistics, Bilingual, Words.

\section{Introduction}

Knowledge of foreign languages and computer technologies are the most important requirements to the level and quality of education of any specialist in various fields. The issue of the training competitive, creative specialists capable of critical thinking, mobility, non-standard solutions to professional problems becomes relevant [6]. In recent years, the use of new information technologies in all spheres has been increasingly raised. This is not only new technical means, but also a new approach in training IT specialists, due to the fact, that computerization and application of new information technologies is an integral part of training highly skilled professionals whose job is to ensure the integrity of such technologies. Nowadays one of the prior directions of the development of education is to improve the quality of professional education in the field of IT-technologies [12].

This is due to the total computerization of all spheres in modern life. For all information technology professionals (or IT professionals) the main language of digital technology is English. No matter how well the operating systems and other software are localized, there are always cases when the computer issues a message in English. Knowledge of English computer terms for all IT specialists is a must and necessity. English is at the heart of all programming languages, all the manuals for software products, descriptions and instructions are written in the overwhelming majority of cases in English [3].

Consequently, possession of a certain degree of English and IT terms for an IT specialist is a prerequisite for their qualification and competitiveness [10].

The relevance of the topic is due to the fact that an essential problem for many IT professionals is the insufficient level of knowledge of computer terms, which causes significant difficulties decreasing effectiveness [5]. The abovestated problem presents significant importance and worth discussing for this reason is the basic research topic of the project.

The purpose of the project is to identify the impact and effectiveness of IT terminology awaraness on the professional competence of specialists.

The subject of the project is the technology of studying IT terms in training specialists.

The hypothesis of the research work is that awareness of IT terminology on the appropriate level increases the professional competence of IT specialists.

According to Eshet-Alkalai [7], digital literacy involves more than just an ability to use tools; it encompasses a large variety of skills, which students need to function effectively in digital environments. The scholar (ibid.) proposed a five-skill holistic conceptual model, arguing that the model covers most of the cognitive skills students use in digital environments: (1) photovisual digital thinking; (2) reproduction digital thinking; (3) branching digital thinking; (4) information digital thinking; and (5) socio-emotional digital thinking. Due to the rapid evolution of multimedia, Eshet-Alkalai also added real-time digital thinking to the model [7].

In the modern society, the role of foreign languages is increasing. Learning languages is more effective when students have the opportunity to use it for specific purpose [8].

It is evident that knowledge of English is an important component in professional competence of a programmer. English-speaking programmers have a better developed reaction to communicate with the operating system and programs during the interactive dialogue, they solve problems of debugging and editing of software products faster, find errors faster and master the documents that have not been translated yet [4].

What does English mean for a programmer? Firstly, in own professional activities s/he needs the ability to extract the necessary information from a variety of sources in English, to understand English technical texts [9]. This includes various manuals, official papers, message windows, commands, training programs, certification tests, 
license agreement terms, correspondence with other developers. Consequently, the choice of names for variables, classes and functions, tables and fields of databases play an important role in the successful development of the project, because the productivity of programmers depends on the convenience of reading the code. In addition, it is customary to comment on the code also in English. Moreover, IT specialists have to correspond with foreign colleagues, clients or partners while concluding contracts, solving problems of troubleshooting. Correct and competent use of professional terms proves confidence that you are a qualified specialist. Possession of technical English gives an advantage to IT professionals and is one of the components of their professional skills [2].

Good command of English also opens up access to a huge number of conferences and seminars taking place around the world. Knowledge of the language will be required to participate in the development of various Open Source projects, thereby gaining a very useful experience [8].

If you combine English with Computing, apply your analytical skills to technical issues that arise in computing information systems, or apply your creativity to areas of computing that take human cognition, you will emerge with a broad range of transferable and employment-related skills [1].

\section{Methods}

To solve the set tasks a number of mutually complementary general scientific and pedagogical methods were used. Theoretical methods in different versions (analysis and synthesis, abstraction and specification, idealization, modeling, forecasting, design) were used to study philosophical, scientific, psychological, pedagogical and methodical literature on the research problem. Empirical methods (study and generalization of pedagogical experience, conversations with students, graduates and teachers, lecturers' and specialists' expert judgment, experimental work) were used in the organization and carrying out the educational process. Experimental base of the research was Kazan (Volga region) Federal University.

To identify the impact and effectiveness of IT terminology awareness on professional skills an online survey was conducted among IT specialists (programmers, Web developers, database administrators, information security analysts, software developers and technical support engineers) and students of Kazan Federal University. The questionnaire was held in groups of "Business Informatics", "Fundamental Informatics and Information Technologies", “Applied Informatics", "Applied Informatics and Mathematics", and "Information Systems and Technologies".

The questionnaire included the following questions:

1. What is your level of English?

A) Intermediate B) Upper - intermediate C) Advanced

2. Do you use English computer terms for your job/study?

$\begin{array}{lll}\text { A) Yes, I do } & \text { B) No, I don't } & \text { C) Sometimes }\end{array}$

3. Does the awareness of English computer terminology affect on the competence of IT specialists (your opinion)?

$\begin{array}{llll}\text { A) Yes, it does } & \text { B) It might affect } & \text { C) No, it doesn't }\end{array}$

4. Does the knowledge of technical English, English computer terminology make your job/your studies more productive and effective?

$\begin{array}{lll}\text { A) Yes, it does } & \text { B) No, it doesn't } & \text { C) Sometimes }\end{array}$

5. Is knowledge of English and English computer terminology a binding requirement for an IT specialist?

A) Yes, it is B) No, it isn't C) It depends on an employer

Results

The following tables demonstrate the results of the survey.

\begin{tabular}{|c|c|c|c|c|c|c|}
\hline Answers & $\begin{array}{c}\text { Question 1 } \\
\text { \% }\end{array}$ & $\begin{array}{c}\text { Question 2 } \\
\mathbf{\%}\end{array}$ & $\begin{array}{c}\text { Question 3 } \\
\mathbf{\%}\end{array}$ & $\begin{array}{c}\text { Question 4 } \\
\mathbf{\%}\end{array}$ & $\begin{array}{c}\text { Question 5 } \\
\mathbf{\%}\end{array}$ & $\begin{array}{c}\text { Mean value } \\
\text { \% }\end{array}$ \\
\hline $\mathrm{A}$ & 41 & 74 & 83 & 92 & 66 & 71,2 \\
\hline $\mathrm{B}$ & 40 & 20 & 14 & 8 & 20 & 20,4 \\
\hline $\mathrm{C}$ & 19 & 6 & 3 & -- & 24 & 10,4 \\
\hline
\end{tabular}

Table 1: The Results of the Survey of Students

\begin{tabular}{|c|c|c|c|c|c|c|}
\hline Answers & $\begin{array}{c}\text { Question 1 } \\
\mathbf{\%}\end{array}$ & $\begin{array}{c}\text { Question 2 } \\
\mathbf{\%}\end{array}$ & $\begin{array}{c}\text { Question 3 } \\
\mathbf{\%}\end{array}$ & $\begin{array}{c}\text { Question 4 } \\
\mathbf{\%}\end{array}$ & $\begin{array}{c}\text { Question 5 } \\
\mathbf{\%}\end{array}$ & $\begin{array}{c}\text { Mean value } \\
\text { \% }\end{array}$ \\
\hline $\mathrm{A}$ & 21 & 78 & 90 & 85 & 76 & 70 \\
\hline $\mathrm{B}$ & 35 & 19 & 10 & 15 & 10 & 11,125 \\
\hline $\mathrm{C}$ & 44 & 3 & 0 & -- & 20 & 13.4 \\
\hline
\end{tabular}

Table 2: The Results of the IT Specialists' Survey

Based on the results of the questionnaire, we can draw up the following conclusions: 
- The majority of participants often face problems of terminology at work and training (74\%-78\%);

- The overwhelming number of students and IT specialists believe that knowledge of IT terminology affects the competitiveness of specialists (83\%-90\%);

- The participants noted the impact of IT terminology awareness on their competence and efficiency in work and study $(85 \%-92 \%)$;

- The participants believe that knowledge of English computer terminology should be an obligatory requirement for IT specialists $(66 \%-76 \%)$.

Figure 1 shows that the majority of participants (74\%-78\%) quite often meet terminological problems during work and training.

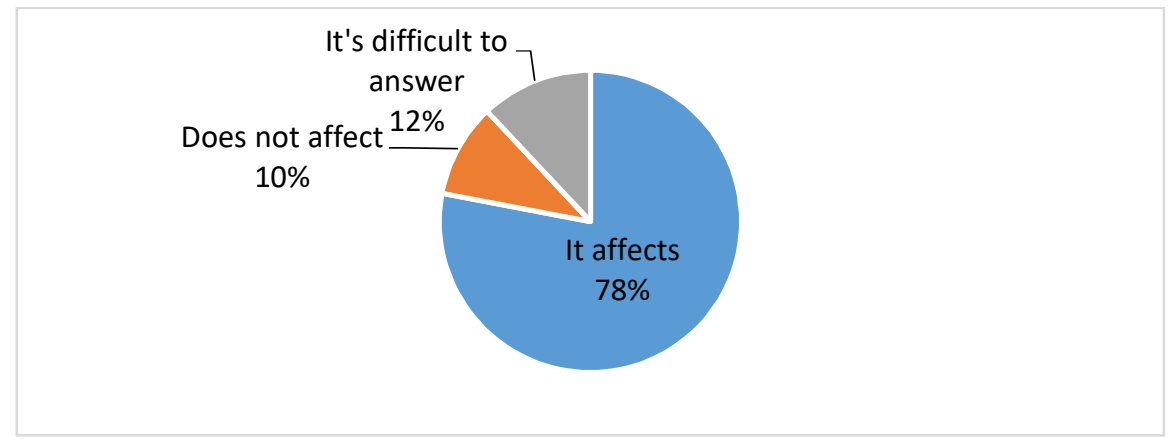

Fig.1: Influence of Mastering IT Terminology on the Competitiveness of a Specialist in Labor Market. Figure 2 shows that overwhelming number of students and IT specialists (83\%-90\%) believe that knowledge of IT terminology affects the competitiveness of a specialist in labor market.

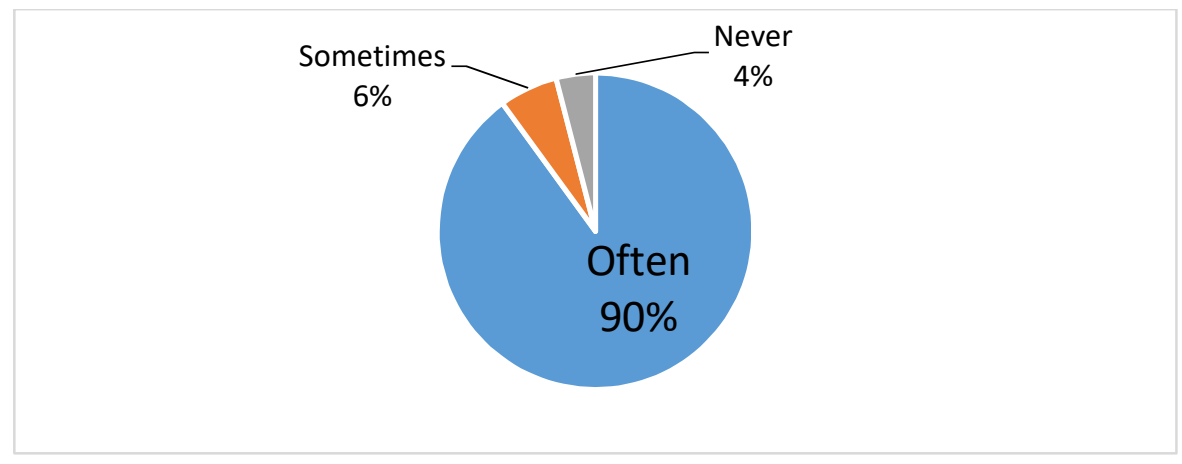

Fig.2: Frequency of Meeting the Problems at Work/Training Caused by the Lack of Mastering IT

\section{Discussion}

\section{Terminology.}

It is evident that to master digital devices and operate on them properly, you will have to be familiar with computer words. Having analyzed the theoretical material and taking into account the results of the survey, the authors defined main reasons proving the importance of computer terminology awareness for IT specialists.

\begin{tabular}{|l|l|}
\hline \multicolumn{1}{|c|}{ Use of English in } & \multicolumn{1}{c|}{ Reasons } \\
\hline Communication & $\begin{array}{l}\text { - knowledge of English improves the response when communicating with the } \\
\text { operating system during the interactive dialogue; programmers often have to } \\
\text { communicate, negotiate, draft technical assignment, and interact during the } \\
\text { implementation of projects, making contracts, solving problems of troubleshooting. }\end{array}$ \\
\hline Programming & $\begin{array}{l}\text { - problems of debugging and editing are solved much faster; } \\
\text { - the process of the system's reaction to erroneous situations and purely professional } \\
\text { aspects of a programmer's activity is realized effectively; } \\
\text { - programming languages are based on English words. }\end{array}$ \\
\hline Troubleshooting & $\begin{array}{l}\text { - choice of names for variables, classes and functions, tables and fields of databases } \\
\text { play an important role in the successful development of a project; } \\
\text { - looking for a solution to the problems on the World Wide Web and searching for } \\
\text { the necessary information. }\end{array}$ \\
\hline $\begin{array}{l}\text { Search } \\
\text { for information }\end{array}$ & $\begin{array}{l}\text { - familiarization and search activity in English occupies an important place in the } \\
\text { professional training of programmers; }\end{array}$ \\
\hline
\end{tabular}




\begin{tabular}{|l|l|}
\hline Gaining experience & - fundamental specialized literature. \\
\hline Computing & $\begin{array}{l}\text { - attending classes, seminars and webinars from well-known IT gurus are in English, } \\
\text { as a result, attending such events is extremely useful for professional, personal } \\
\text { growth gaining useful experience. }\end{array}$ \\
\hline $\begin{array}{l}\text {-combining English with Computing, applying analytical skills to technical issues } \\
\text { that arise in computing information systems, or applying creativity to areas of } \\
\text { computing that take human cognition with a broad range of transferable and } \\
\text { employment-related skills. }\end{array}$ \\
\hline
\end{tabular}

Table 3: The List of Reasons to Master IT Terminology

Finally, awareness of IT terminology on the appropriate level increases professional competence of IT specialists. IT professionals and software engineers need to have a good vocabulary of computer terms as one of the components of professional skills.

\section{Conclusion}

Thus, it is evident that knowledge of IT terminology is one of the professional skills of IT specialists. Awareness of the terms makes their work and study more productive and effective. Based on the results of the questionnaire, we can draw up the following conclusions.

The majority of participants meet the terminological problems at work and training. Overwhelming number of students and IT specialists believe that knowledge of IT terminology affects their competitiveness. Almost all participants noted the impact of IT terminology awareness on their competence and efficiency in work and study. According to the results of the questionnaire, knowledge of English computer terminology should be an obligatory requirement for IT specialists.

As a result, we can state that most participants of the survey are convinced of the necessity to master English terminology for IT professionals. The percentage relationship between the results of the responses of IT specialists and students is not much of a difference.

\section{Acknowledgments}

The work is performed according to the Russian Government Program of Competitive Growth of Kazan Federal University.

\section{References}

[1] M.M. Abdurazakov, J.H. Aziyeva, P.Yu. Romanov, A.R. Sadykova "Teachers IT competence structure and content in the field of cloud computing" in International Conference on Education Environment for the Information Age (EEIA), JUN 07-08, 2017, pp.1-8.

[2] D. Akhmed-Zaki, M. Mansurova, A. Pyrkova "Development of courses directed on formation of competences demanded on the market of IT technologies" in Zone 1 Conference of the American-Society-for-EngineeringEducation (ASEE Zone), APR 03-05 2014, 2014.

[3] A.R. Baranova, K.I. Kalimullina "Comparison of Methods for classifying data for division into groups when learning English” in Revista Publicando, 4 No 13. (1). 2017, pp. 563-573.

[4] A.R. Baranova, A.A. Valeev "Pedagogical conditions of students' self-realization capacity development" in The Social Sciences 11 (14): 3618-3622, 2016.

[5] J. Engelbrecht, K.A. Johnston, V. Hooper "The influence of business managers' IT competence on IT project success" in International Journal of Project Management. Vol. 35, Issue 6. AUG 2017, pp. 994-1005.

[6] G.R. Eremeeva, R.R. Bikbulatov, A.R. Baranova "Pedagogical conditions necessary for training teachers to manage the development of intellectually gifted students" in Proceedings of the 7th International Scientific and Practical Conference Current Issues of Linguistics and Didactics: the Interdisciplinary Approach in Humanities (CILDIAH 2017). Vol. 97. November 2017. pp. 37-41.

[7] Y. Eshet-Alkalai "Digital literacy: A conceptual framework for survival skills in the digital era" in Journal of Educational Multimedia and Hypermedia, 13(1), 2004, pp. 93-106.

[8] R. Gintaute-Marihina "Cooperation Methods Using in E-Learning for It Specialists' Competence Development" in International Scientific Conference on Society, Integration, Education. MAY 22-23, 2015, pp. 405-414.

[9] Mehmet Cem Odacioglu and Saban Kokturk "The Effects of Technology on Translation Students in Academic Translation Teaching" in Procedia - Social and Behavioral Sciences. Vol. 197, 25 July 2015, pp. 1085-1094.

[10] S. Somyurek, B.K. Coskun "Digital competence: Is it an innate talent of the new generation or an ability that must be developed?" in British Journal of Educational Technology. Vol. 44, Issue 5,SEP 2013, pp. E163-E166.

[11] N.A. Sigacheva, A.R. Baranova, G.K. Gizatova, R.R. Fahrutdinov, (2017). Specifics of computer discourse translation from English into Russian. J Fundam Appl Sci. 9(7S), 1231-1238.

[12] O.V. Vishtak, I.V. Mikheye, I.A. Shtyrova "The use of the Computer Training System as The Factor of Effective Formation of Information Competence of Future IT-Specialists" in International Scientific-Practical Conference on Information Technologies in Education of the XXI Century (ITE-XXI) DEC 07-08, 2015 in AIP Conference Proceedings Vol. 1797 Article No. UNSP 020018, 2017. 